\title{
UCID - 16756
}

This is an informal report intended primarily for internal or limited external distribution. The opinions and conclusions stated are those of the author and may or may not be those of the laboratory.

\section{L \\ LAWRENCE LIVERMORE LABORATORY \\ University of California/Livermore, California}

\author{
DT FUSION NEUTRON IRRADIATION OF LLL NIOBIUM TENSILE SPECIMEN, \\ LASL-BNL SUPERCONDUCTOR WIRES, LLL MOLYBDENUM, \\ VANADIUM AND ALUMINUM, LLL GRAPHITE, ORNL \\ MAGNESIUM OXIDE CRYSTAL, SLL-LLL NATURAL \\ QUARTZ, SYNTHETIC QUARTZ AND SUPRACIL, \\ ANL ELECTRON MICROSCOPY SAMPLES AND \\ SLL FIBER OPTIC BUNDLES \\ UNCLASSIFIED \\ Susan MacLean \\ March 17, 1975




\section{DISCLAIMER}

This report was prepared as an account of work sponsored by an agency of the United States Government. Neither the United States Government nor any agency Thereof, nor any of their employees, makes any warranty, express or implied, or assumes any legal liability or responsibility for the accuracy, completeness, or usefulness of any information, apparatus, product, or process disclosed, or represents that its use would not infringe privately owned rights. Reference herein to any specific commercial product, process, or service by trade name, trademark, manufacturer, or otherwise does not necessarily constitute or imply its endorsement, recommendation, or favoring by the United States Government or any agency thereof. The views and opinions of authors expressed herein do not necessarily state or reflect those of the United States Government or any agency thereof. 


\section{DISCLAIMER}

Portions of this document may be illegible in electronic image products. Images are produced from the best available original document. 


\section{DT FUSION NEUTRON IRRADIATION OF LLL NIOBIUM TENSILE SPECIHEN \\ LASL-BNL SUPERCONDUCTOR WIRES, LLL MOLYBDENUM, VANADIUM AND ALUMINUM, LLL GRAPHITE, ORNL MAGNESIUM OXIDE CRYSTAL, SLL-LLL NATURAL QUARTZ, SYNTHETIC QUARTZ AND SUPRACIL, \\ ANL ELECTRON MICROSCOPY SAMPLES AND \\ SLL. FIBER OPTIC BUNDLES}

UNCLASSIFIED

Susan C. MacLean

March 17, 1975

For most efficient utilization of the LLL Rotating Target Neutron Source (RTNS), samples from several experimenters were combined for the irradiation run beginning February 12, 1975.

Urs. Jack B. Mitchell and Richard A. Van Konynenburg of LLL provided a niubium tensile specimen for irradiation. Two 1 mil thick niobium dosimetry foils were cut the same size and shape as the tensile specimen.

Three superconductor wires were being irradiated to a fluence of $10^{18}$ neutrons $/ \mathrm{cm}^{2}$ for Dr. Don M. Parkin of Los Alamos Scientific Laboratory (LASL) and Dr. C.L. Snead, Jr. of Brookhaven National Laboratory (BNL). The wires, 19-core multifilament $\mathrm{ib}_{3} \mathrm{Sn}$ wires in a bronze matrix, had been irradiated October 1-4, 1973, December 3-7, 1973, December 10-12, 1973, January 14-16, 1974, March 11-14, 1974, May 20-23, 1974, May 29-31, 1974, January 6-14, 1975, and January 21-February 4, 1975. 
Dave Hosmer, Dr. J. Birch Holt and Dr. Gordon S. Smith, all of LLL, provided 14 graphite samples measuring approximately $12 \mathrm{~mm}$ square; nine molybdenum foils ( $1 \mathrm{mil}$ thick), eight vanadium foils ( $1.5 \mathrm{mils}$ thick), and eight aluminum foils $(1.25$ mils thick) for irradiation. They intended to measure helium generation in the samples.

A magnesium oxide crystal, Mg0-8, was being irradiated to a fluence near $10^{18}$ neutrons $/ \mathrm{cm}^{2}$ for Dr. Yok Chen of Oak Ridge National Laboratory. The crystal had previously been irradiated January 14-16, 1974, May 29-31, 1974, July 16-18, 1974, September 11, 1974, October 7-9, 1974, October 25, 1974, November 7-13, 1974, December 2-6, 1974, January 6-14, 1975, and January 21February 4, 1975.

Michael Moran of LLL and Dr. Peter L. Mattern of Sandia Livermore Laboratory (SLL) provided ten quartz samples, eight supracil samples, one natural quartz sample, and one Zcut, synthetic quartz sample for irradiation. The natural quartz sample measured approximately $10 \times 20 \times 3 \mathrm{~mm}$ and the Zcut, synthetic quartz was about $10 \times 10 \times 2 \mathrm{~mm}$. Varying fluences within the range of $10^{10}$ to $10^{16}$ neutrons $/ \mathrm{cm}^{2}$ were requested for the quartz and supracil samples. Their sizes varied but they measured approximately $2 \times 3 \times 10 \mathrm{~mm}$.

Dr. Karl L. Merkle of Argonne National Laboratory (ANL) requested irradiation of a copper cylinder measuring approximately $3 / 8$ inch in diameter and 2 inches long. The cylinder contained samples to be examined by electron microscopy following irradiation. 
Fifteen fiber optic bundles were provided for irradiation by Dr. Lawrence M. Watkins of Sandia Livermore Laboratory (SLL). The bundles were wound in concentric circles of diameters from $10-1 / 2$ inches to about 13 inches. Nine fiber optic bundles were taped on the front of a $60 \mathrm{mil}$ thick lucite disc and six bundles were taped to the back. Six niobium dosimetry discs, 5 mils thick, $12 \mathrm{~mm}$ in diameter, were taped to the bundles (three in front, three in back) in positions corresponding to 4 o'clock, $80^{\prime}$ clock, and 12 o'clock.

The samples were fastened to 13 sample holders and arranged along three aluminum rods. The first rod was in a straight line with the neutron beam and the front sample holder, A, contained six stacks of samples. The niobium tensile specimen, the superconductor wires, the molybdenum, the vanadium, the aluminum, and part of the graphite were centered with the neutron source. The niobuim dosimetry foils used were 1 mil thick and, except for those on the tensile specimen and graphite samples, were $12 \mathrm{~mm}$ diameter discs. All the dosimetry foils sandwiching the graphite samples were $1 \mathrm{mil}$ thick and approximately $12 \mathrm{~mm}$ square. A second stack of graphite samples was to the right (as seen from the neutron source) of the centered pile on the sample holder A. Mg0-8 with 1 mil thick, $12 \mathrm{~mm}$ diameter dosimetry foils was to the left of the centered stack of samples. The natural quartz, quartz Q-10 and supracil S-8 together, and the Zcut, synthetic quartz had 1 mil thick niobium dosimetry foils cut to the same size and shape as the 
samples. These samples were above the centered stack in a single layer, horizontal row. Left to right as viewed from the neutron source, they were in the order listed except that S-8 was directly above Q-10.

The second sample holder, $B$, on the first rod, held Merkle's capsule with a one mil thick, $12 \mathrm{~mm}$ diameter niobium dosimetry foil directly on the front of the capsule. A doughnut shaped dosimetry foil was cut from 5 mi 1 thick niobium foil to fit snugly aound the capsule. This was placed at the line on the capsule indicating the end of the samples inside. Sample holder A had a hole in jt that was covered on the front with mylar. Therefore, Merkle's capsule could be held right up behind the center samples on the first holder, flush with the mylar.

The lucite supporting the fiber optic bundles was the third sample holder on the first rod.

A second rod was used for seven sample holders. Six sample holders held both supracil and quartz samples side by side on a niobium dosimetry foil. The last sample holder held supracil only. The dosimetry foils on the first four sample holders were $5 \mathrm{mil}$ thick, $12 \mathrm{~mm}$ diameter discs. The foils on the last three sample holders of the second rod were $5 \mathrm{mil}$ thick niobium measuring approximately one inch square.

The third rod held three sample holders each with one quartz sample. The first sample holder $(K)$ on this rod had two dosimetry foils, 5 mils thick and one inch square. The other two holders each had four niobium foils 5 mils thick and one inch square. 
THIS PAGE

\section{WAS INTENTIONALLY LEFT BLANK}




\begin{tabular}{|c|c|c|}
\hline Order & Sample Holder & Sample \\
\hline 20. & & $v-2$ \\
\hline 21. & & $V-3$ \\
\hline 22. & & $V-4$ \\
\hline 23. & & $V-5$ \\
\hline 24 & . & $V-6$ \\
\hline 25. & & $v-7$ \\
\hline 26. & & $V-8$ \\
\hline 27. & & $N b-293$ \\
\hline 28 & & $N b-290$ \\
\hline 29 . & & Al-1 \\
\hline 30. & & Al-2 \\
\hline 31. & $A$ & Al-3 \\
\hline 32. & & Al-4 \\
\hline 33. & & Al-5 \\
\hline 34. & & Al -6 \\
\hline 35. & & Al-7 \\
\hline 36. & & $A 1-8$ \\
\hline 37. & & $N b-291$ \\
\hline 38. & & $N b-288$ \\
\hline 39. & & Graphite $\mathrm{H}-1$ \\
\hline 40. $\begin{array}{l}(\mathrm{Br} \\
\mathrm{ar}\end{array}$ & $\begin{array}{l}\text { groups } \\
\text { side by side) }\end{array}$ & Graphite $\mathrm{H}-2$ \\
\hline 41. & & Graphite $\mathrm{H}-3$ \\
\hline
\end{tabular}




\begin{tabular}{|c|c|c|c|}
\hline Order & Sample Holder & $\underline{\text { Sample }}$ & $\begin{array}{c}\text { Distance from } \\
\text { Source } \\
\end{array}$ \\
\hline 42. & & Graphite H-4 & \\
\hline 43. & & Graphite $\mathrm{H}-5$ & \\
\hline 44. & & Graphite $H-6$ & \\
\hline 45. & & Nb-289 & \\
\hline 46. & $\therefore$ & Nb-304 & \\
\hline 47. & & Graphite $\mathrm{H}-7$ & \\
\hline 48. & & Graphite H-8 & \\
\hline 49. & & Graphite H-9 & \\
\hline 50. & & Graphite $\mathrm{H}-10$ & \\
\hline 51. & & Graphite $H-11$ & \\
\hline 52. & A. & Graphite $\mathrm{H}-12$ & \\
\hline 53. & $\ldots$ & Graphite $H-13$ & \\
\hline 54. & & $\mathrm{Nb}-305$ & \\
\hline 55. & & $N b-306$ & \\
\hline 56. & & Graphite $\mathrm{H}-14$ & \\
\hline 57. & & $\mathrm{Nb}-307$ & \\
\hline 58. & & Nb-296 & \\
\hline 59. & & Mg0-8 wrapped in aluminum & oil \\
\hline 60. & & $N b-297$ & \\
\hline 61. & & NNb-302 & \\
\hline 62. & & Natural quartz & \\
\hline 63. & & $N b-303$ & \\
\hline
\end{tabular}




\begin{tabular}{|c|c|c|c|}
\hline Order & Sample Holder & Sample & $\begin{array}{c}\text { Distance from } \\
\text { Source } \\
\end{array}$ \\
\hline 64. & & $N b-308$ & \\
\hline 65. & $\therefore$ & S-8 and Q-10, side by side & \\
\hline 66. & $A$ & $\| N b-309$ & \\
\hline 67. & & ivb-300 & \\
\hline 68. & & Z cut, synthetic quartz & \\
\hline 69. & & {$[\mathrm{inb}-301$} & \\
\hline 70. & & $\int N b-310$ & \\
\hline 71. & $B$ & $\{$ Merkle's capsule & \\
\hline 72. & & $\mathrm{Nb}-331$ & \\
\hline 73. & . & (Nb-311 (12 o'clock position) & $216 \mathrm{~mm}$ \\
\hline 74. & . & $\mathrm{Nb}-328$ (4 o'clock position) & \\
\hline 75. & . & Nb-313 (8 o'clock position) & \\
\hline 76. & . C & $\{$ Fiber optic bundles & \\
\hline 77. & & Nb-312 (12 o'clock position) & \\
\hline 78. & & Nb-329 (4 o'clock position) & \\
\hline 79. & $\dot{y}$ & (Nb-330 (8 o'clock position) & \\
\hline & rod & $\therefore \cdot$ & \\
\hline 80. & & $\mathrm{Nb}-314$ & $31 \mathrm{~mm}$ \\
\hline 81. & 0 & $\{\operatorname{Sin}$ and $Q-9$ & \\
\hline 82. & $\therefore$ & $N b-318$ & \\
\hline
\end{tabular}




\begin{tabular}{|c|c|c|c|}
\hline Order & Sample Holder & Sample & $\begin{array}{c}\text { Distance from } \\
\text { Source } \\
\end{array}$ \\
\hline 83. & & $\int N b-315$ & $68 \mathrm{~mm}$ \\
\hline 84. & $E$ & $\{S-6$ and $Q-8$ & \\
\hline 85. & & {$[N b-3.19$} & \\
\hline 86. & & $\int N b-316$ & $96 \mathrm{~mm}$ \\
\hline 87. & $\mathrm{~F}$ & $\{S-5$ and $Q-7$ & \\
\hline 88. & & $\mathrm{Nb}-320$ & \\
\hline 89. & & $\{N b-317$ & $216 \mathrm{~mm}$ \\
\hline 90. & $G$ & $\{\mathrm{~S}-4$ and $Q-6$ & \\
\hline 91. & & $(n b-32]$ & \\
\hline 92. & $H$ & $\int \mathrm{S}-3$ and $\mathrm{Q}-5$ & $306 \mathrm{~mm}$ \\
\hline 93. & . & Nb-322 & \\
\hline 94. & I & $\{S-2$ and $Q-4$ & $684 \mathrm{~mm}$ \\
\hline 95. & & $N b-323$ & \\
\hline 96. & $\mathrm{~J}$ & $\{s-1$ & $967 \mathrm{~mm}$ \\
\hline 97. & & $\{\mathrm{Nb}-324$ & \\
\hline \multicolumn{4}{|c|}{ Third rod } \\
\hline 98. & \multirow[t]{2}{*}{ K } & $\{Q-3$ & \multirow[t]{2}{*}{$221 \mathrm{~mm}$} \\
\hline 99. & & LNb-325a+b & \\
\hline 100. & \multirow[t]{2}{*}{$L$} & $\left\{\begin{array}{l}Q-2 \\
\text {. }\end{array}\right.$ & \multirow[t]{2}{*}{$698 \mathrm{~mm}$} \\
\hline 101. & & $(N \mathrm{Nb}-326 \mathrm{a}, \mathrm{b}, \mathrm{c}+\mathrm{d}$ & \\
\hline 102. & \multirow{2}{*}{ M } & $\{0-1$ & \multirow[t]{2}{*}{2.31 meters } \\
\hline 103. & & $\lfloor\dot{N} b-327 a, b, c,+d$ & \\
\hline
\end{tabular}


The irradiation was carried out by the LLL E Division Accelerator Staff during the period February 12 to 14,1975 . The third rod, containing sample holders $K, L$, and $M$, was removed after 30 minutes of irradiation on February 12, 1975. Neutron production was monitored continuously with a proton recoil counter and recorded each hour. The dose record is attached. Total beam-on time was 45.82 hours.

The sample holder assemblies were removed and stored for a few days to allow for decay of short-lived isotopes. An autoradiograph of the front sample holder, $A$, indicated that the centering of the samples had been with in $1 \mathrm{~mm}$ of the center of the neutron source.

The samples were all returned to the experimenters except for the aluminum, vanadium, and molybdenum. These were stored until the samples decayed enough and they could be safely handled and tested for helium content.

The two tensile-specimen shaped dosimetry foils were cut so that only the sections corresponding to the tensile sample gauge portion were weighed. These along with the other niobium dosimetry foils and one each of the aluminum, vanadium, and molybdenum foils, were delivered to Ruth Anderson in the LLL Radiochemistry Division. She carried out the gamma ray counting of the foils. The average fluence of each niobium dosimetry foil was calcuiated using the method described in UCRL-51393, Rev. 1. However, the value used for the niobium cross section for activation of the 10.16 day isomer was changed to $458 \mathrm{~m}$ barns for $14.8 \mathrm{Mev}$ neutrons. The results were as follows: 
Sample holder A:

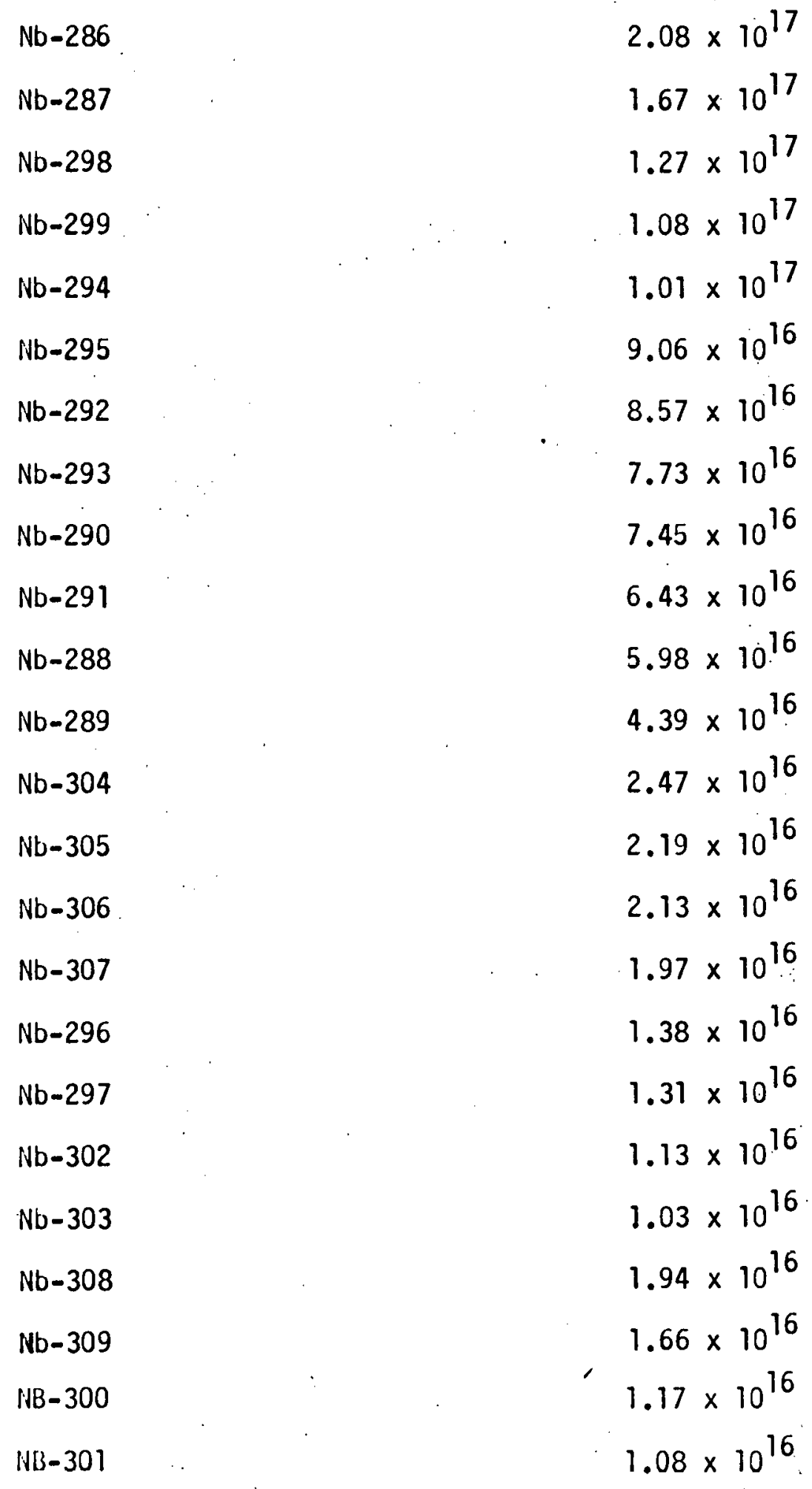


Dosimetry Foil Number

Sample holder B:

$\begin{array}{ll}\text { NB-310 } & 4.11 \times 10^{16} \\ \text { NB-331 } & 1.86 \times 10^{15}\end{array}$

Sample holder $C$ :

$\begin{array}{ll}N b-311 & 8.78 \times 10^{13} \\ N B-328 & 8.81 \times 10^{13} \\ N B-313 & 8.83 \times 10^{13} \\ \text { NB-312 } & 7.56 \times 10^{13} \\ \text { NB-329 } & 7.59 \times 10^{13} \\ \text { NB-330 } & 7.48 \times 10^{13}\end{array}$

Sample holder D:

NB-314

NB -318

Sample holder E:

NB- 315

NB-319

Sample hoīder F:

$N B-316$

NB- 320
Fluence (neutrons $/ \mathrm{cm}^{2}$

$4.11 \times 10^{16}$
$1.86 \times 10^{15}$

$8.78 \times 10^{13}$

$8.81 \times 10^{13}$

$8.83 \times 10^{13}$

$7.56 \times 10^{13}$

$7.59 \times 10^{13}$

$7.48 \times 10^{13}$

$3.71 \times 10^{15}$

$3.03 \times 10^{15}$

$8.97 \times 10^{14}$

$7.94 \times 10^{14}$

$4.39 \times 10^{14}$

$4.08 \times 10^{14}$ 
Dosimetry Foil Number

Sample holder G:

$$
\begin{aligned}
& N b-317 \\
& N B-327
\end{aligned}
$$

Sample holder $H$ :

$$
\mathrm{Nb}-322
$$

Sample holder I:

$$
\mathrm{Nb}-323
$$

Sample holder J:

$$
N b-324
$$

Sample holder K:

$$
N b-325 a+b
$$

Sample holder L;

$$
N b-326 a, b, c+d \quad 8.39 \times 10^{10}
$$

Sample holder M:

$$
\mathrm{Nb}-327 \mathrm{a}, \mathrm{b}, \mathrm{c}+\mathrm{d} \quad 3.63 \times 10^{9}
$$

The estimated overall uncertainty of these results is $\pm 7.5 \%$. The relative uncertainty between any two values is about $\pm 2 \%$. The values given here represent average fluences over the volume of each dosimetry foil. 
The helium generated in the aluminum samples was calculated using the gamma ray count of Al-5 sample. The neutron fluence for the sample was calculated as described in UCRL-51393, Rev. 1, using values appropriate for the reaction ${ }^{27} \mathrm{Al}(n, a)^{24}$ iva. The number of helium atoms formed was obtained by multiplying the cross section for the reaction by the fluence. Thus, having the number of helium atoms (parts per billion) for Al-5, and the fluences for niobium dosimetry foils (of known thickness) at both ends of the stack of aluminum samples (of known thickness), the helium generated for each sample was calculated by interpolation. The results were as follows:

$\begin{array}{lc}\text { Sample } & \text { Helium Atoms (Atomic ppb) } \\ \text { Al-1 } & 8.33 \\ \text { Al-2 } & 8.20 \\ \text { Al-3 } & 8.07 \\ \text { Al-4 } & 7.93 \\ \text { Al-5 } & 7.80 \\ \text { Al-6 } & 7.66 \\ \text { Al-7 } & 7.53 \\ \text { Al-8 } & 7.40\end{array}$

The estimated overall uncertainty of these results is about $\pm 3 \%$. 
Two $(n, a)$ reactions occur in vanadium to produce helium: ${ }^{51} V(n, a)^{48} \mathrm{Sc}$ and ${ }^{50} V(n, a)^{47} S c$. Since ${ }^{50} V$ accounts for only $0.24 \%$ of the vanadium, this reaction produces an insignificant amount of helium compared to that formed from ${ }^{51} V$. Using the gamma ray count of sample $V-4$, the number of helium. atoms formed for each vanadium sample was calculated in the same manner as described for the aluminum samples. The results were as follows:

Sample

$$
v-1
$$

$v-2$

$v-3$

$\checkmark-4$

$$
v-5
$$

$V-6$

$V-7$

V-8
Helium Atoms (ppb)

1.49

1.47

1.46

1.44

1.42

1.40

1.39

1.37

The estimated overall uncertainty of these results is about $\pm 3 \%$. 


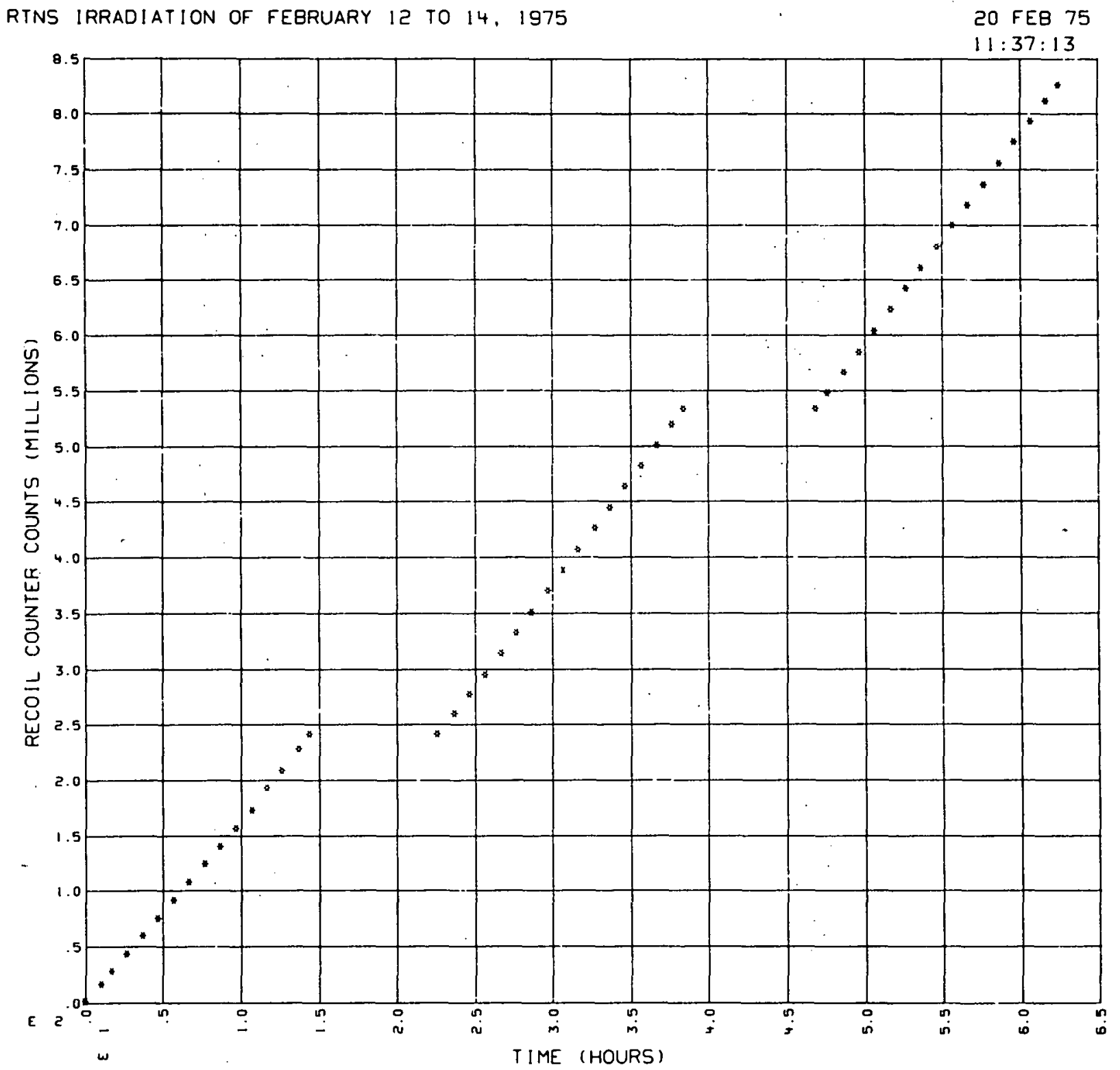


LLL Internal Distribution

J.D. Anderson, L-312

J.C. Davis, L-313

C.M. Logan, L-313

C. Wong, L-313

R. Booth, L-330

J.W. Frazer, L-401

L.W. Roberts, L-401

R.J. Borg, L-23]

C. Gatrousis, L-231

L.G. Mann, L-540

R.N. Anderson, L-23I

R.R. Vandervoort, L-426

J.B. Mitche 11, L- L-426

M.W. Guinan, L-2.33

R.A. Van Konynenburg, L-233

J.B. Holt, L-503

D. Hosmer, L -503

M. Moran, L-503

M. Schwab, L-503

G.S. Smith, L-503

S.C. MacLean, L-233 (9 copies)

TID FILE, L $\div 9$ ( 42 copies)
External Distribution

Dr. Klaus Zwilsky, USERDA

Division of Controlled Thermonuclear. Research

Washington, D.C. 20545

Dr. Marvin Cohen, USERDA

Division of Controlled Thermonuclear Research

Washington, D.C. 20545

Dr. Charles Finfgeld, USERDA

Division of Controlled Thermonuclear Research

Washington, D.C. 20545

Dr. Louis Ianneillo, USERDA

Division of Physical Research

Washington, D.C. 20545

Dr. C.Z. Serpon; Jr., USERDA

Reactor Safety Research

Washington, D.C. 20545

Dr. Robert Heinrich

Argonne National Laboratory B1dg.205

9700 South Cass Avenue

Argonne, IL 60439

Dr. Yok Chen

Oak Ridge National Laboratory

P.0. Box X

Oak Ridge, TN 37830

Dr. Marvin Abraham

Oak. Ridge National Laboratory

P.0. Box X

Oak Ridge, TN 37830 


\section{External Distribution (cont'd)}

Ur. Don M. Parkin

Los Alamos Scientific Laboratory

P.0. Box 1663

Los Alamos, NM 87544

Ur. C.L. Snead, Jr.

Brookhaven National Laboratory

Isotope and Special Materials Group

Upton, NY. 11973

Dr. Peter L. Mattern

Sandia Livermore Laboratory

East Avenue

Livermore, CA 94550

Dr. Lawrence M. Watkins

Sandia Livermore Laboratory

East Avenue

Livermore., CA 94550

Or. Karl L. Merkle

Argonne National Laboratory

Materials Science Division

Argoinne, IL 60439

NOTICE

"This report was prepared as an account of work sponsored by the United States Government. Neither the United States nor the United States Energy Research \& Development Administration, nor any of their employees, nor any of their contractors, subcuntracturs, or their empluyees, makes ally warranty, express or implied, or assumes any legal liability or responsibility for the accuracy. completeness or usefulness of any information, apparatus, product or process disclosed, or apparatus, product or process disclosed, or
represents that its use would not infringe privately-owned rights." 